\title{
Analysis of Information Systems Management (post)Graduate Program: Case Study of Faculty of Economics, University of Ljubljana, Slovenia
}

\author{
Peter Baloh \\ Faculty of Economics, University of Ljubljana, Slovenia
}

peter.baloh@ef.uni-lj.si

\begin{abstract}
Only a strong interaction of people, information and technology can improve business performance. The Chief Information Officer (CIO) of the new age has to be a 'hybrid' business and information systems manager who can play a major role in strategy formulation for effective use of information technology, who does not neglect the human side of the information equation, and who does not forget that information has to be managed like any other resource and thus puts the 'I' back in the 'IT'. This leads to new aspects of what kind of competencies and skills a CIO, a 'hybrid' business and information systems manager, must have.

In the paper a recently developed Information Systems Management under- and post-graduate curriculum is verified whether it sustains sufficient degree of relevancy to the needs of presentday business community. This analysis can serve as a guideline when building, revising and endorsing contemporary and relevant curricula for similar educational programs.
\end{abstract}

Keywords: business-information systems, information management, education curriculum, information orientation, IT productivity paradox

\section{Introduction}

To succeed in the global marketplace, companies must reposition themselves to tap the sources of sustainable growth. One of the characteristics of the information era transition period is that, in comparison to the traditional raw materials processing, information processing has become instrumental in businesses' success. At the same time, the information era transition has contributed to businesses' competitiveness, shortened their responsiveness to environmental changes, and enlarged the inventory of business practices for successful market performance.

Why do than so many companies, who yearly spend billions on new technological solutions, struggle to understand how to put information to work so that it would support business and improve business performance. As suggested by Davenport, 2000, the reason for sparse harvest is "technological obsession" which links company's competitive advantages exclusively with IT investments. IT vendors and consultants claim to have panacea for every possible business 'situa-

Material published as part of this journal, either on-line or in print, is copyrighted by Informing Science. Permission to make digital or paper copy of part or all of these works for personal or classroom use is granted without fee provided that the copies are not made or distributed for profit or commercial advantage AND that copies 1) bear this notice in full and 2) give the full citation on the first page. It is permissible to abstract these works so long as credit is given. To copy in all other cases or to republish or to post on a server or to redistribute to lists requires specific permission from the publisher at Publisher@InformingScience.org tion', yet they forget to disclose that IT is just one of the (important) factors of a successful information use, which leads to successful achievement of organization's goals. Not only everyday business practice but also academic research shows that "even the most rigorous economists have difficulty finding correlations between IT 
spending and productivity, profits, growth, revenues or any other measure of financial benefit," (Davenport, 2000; see also Strassman, 1990, and Bharadway, 2000).

In spite of that, some do succeed. (Good) business practice has already indicated that successful business informatization or/and transformation of business to e-business models are related to optimization and renovation of business processes, training and motivation of employees, adaptation of organizational structure, general improvement of business culture, information management, etc. Yet, until recently, there was no "complete cookbook recipe". In year 2000, a 28month research study called "Navigating Business Success" was conducted at IMD business school, Lausanne, Switzerland, in conjunction with Andersen Consulting (Marchand, Kettinger, $\&$ Rollins 2000, 2001a). Authors of the research surveyed over 1,000 senior executives from 98 privately and publicly held companies operating in 22 countries and 25 industries. In essence, the results showed that only a strong combination of 1) excellence in investing and deploying technology, 2) excellence in collecting, organizing and maintaining information, and 3) getting the people to embrace the right behaviors and values for working with information, can lead to superior business performance. According to the research, senior managers possess a higher-level idea, 'Information orientation' (IO), which embraces three basic information capabilities that managers associate with effective information use: Information Technology Practices (ITP), Information Management Practices (IMP) and Information Behaviors and Values (IBV). Interesting enough, each of the areas was recognized as important in the past by academia and practitioners, however, they were considered separately in isolated schools of thoughts. "A company must achieve competence and synergy across all three information capabilities of effective information use as a precondition to achieving superior business performance," (Marchand et al., 2000, 2001a).

In the first section each of the information orientation capabilities will be briefly discussed (for in-depth analysis see Baloh, 2004; Marchand et.al., 2001a) as they present how senior management sees the information subsystem of (successful) organization. These capabilities also present CEOs' view on information systems professionals and knowledge workers, on whom each company depends on, since success depends on how fast they utilize proper information. For doing their jobs right their competencies have to be somewhat broader than they used to be and must include ample information technology literacy, information management awareness and proactive information behavior.

Graduate and post-graduate programs that aim to educate future knowledge workers, especially business, information, and business-information professionals, will have to (if they have not already) revise their curricula according to business-world expectations and give their students skills and capabilities that CEOs' call for.

In that sense, a graduate and postgraduate program that has recently been developed at the Faculty of Economics, University of Ljubljana, is revised and verified whether it sustains sufficient degree of relevancy to the needs of present-day business community. This analysis in final section, together with recommendations in content/delivery areas, can serve as a guideline when building, revising and endorsing contemporary and relevant curricula for similar educational programs.

\section{Returning the 'I' in the 'IT'}

In this section information orientation capabilities are discussed as they present how senior management sees the information subsystem of (successful) company. 


\section{Information Technology Practices (ITP)}

This is the realm of software, hardware, telecommunication networks and technical expertise, supporting everything from the tasks of lower-skilled workers to the creation of innovative new products and the analysis of market developments and creation of strategy.

In 1989 Gorry and Scott Morton linked Simon's decision-classification $(1946,1960)$ with Anthony's organizational pyramid (1965) and showed that different IT support is needed at different organizational levels. Marchand et al. (2001a) adapted the Gorry and Scott Morton's framework to today's business conditions (Figure 1). IT for operational support is software, hardware, telecommunication networks and technical expertise that serves to solve structured decisions, ensure quality of data and improve efficiency of transactions. Improvements to IT for operational support have positive effect on both IT for business process support (that support business processes with improving cross-functional process management and by connecting business processes with those of suppliers and customers) and IT for innovation support (which facilitate creativity and speed up the creation of new products and services). In order to become IT-mature, a company has to develop each IT capability due to their interrelations. In order to develop the IT for management support capability (which focuses on the principal strategic decisions managers face, such as market positioning, competitive analysis, and exploration of business opportunities), company has to excel in all other capabilities, as their outcomes serve as support to the capability. Consequently, this is the most difficult dimension to control and develop, yet it is necessary to be developed when a company wants to achieve competitive advantage.

It is so because today providing superior IT for operational and business process support that focus primarily on structured and semi-structured decisions (i.e. transaction processing, SCM...) will not provide strategic competitive advantage, as they are merely necessary to operate business and follow the competitors. One step in providing greatest information asymmetry is to ensure that IT capabilities ensure support not only for control but also innovation - in other words, support for both planned and emergent strategy (Mintzberg, Ahlstrand and Lampel, 1998).

The other necessary steps for achieving industry leadership require excellent information usage behaviors and good information management practices.

\begin{tabular}{|c|c|c|c|c|}
\hline & IT practice support & $\begin{array}{l}\text { Types of knowl- } \\
\text { edge workers }\end{array}$ & $\begin{array}{c}\text { Decision making } \\
\text { levels }\end{array}$ & Application examples \\
\hline \multirow{2}{*}{ 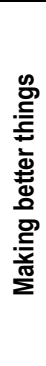 } & $\begin{array}{l}\text { IT } \\
\text { managerial } \\
\text { support }\end{array}$ & $\begin{array}{l}\text { Executives / senior } \\
\text { managers }\end{array}$ & $\begin{array}{l}\text { Strategy } \\
\text { Resource allocation } \\
\text { Management control }\end{array}$ & $\begin{array}{l}\text { Executive information systems (e.g. SAP Net- } \\
\text { Weaver), Business intelligence tools (e.g. SAP } \\
\text { BI, Business Objects), Decision support systems } \\
\text { (DSS), Data mining, On-line analytical process- } \\
\text { ing (OLAP), Group decision support systems, } \\
\text { Financial management systems... }\end{array}$ \\
\hline & $\begin{array}{l}\text { IT } \\
\text { innovation } \\
\text { support }\end{array}$ & $\begin{array}{l}\text { Professional workers } \\
\text { (R\&D, engineering, } \\
\text { product design) }\end{array}$ & $\begin{array}{l}\text { New products / ser- } \\
\text { vices } \\
\text { Improve creativity and } \\
\text { exploration }\end{array}$ & $\begin{array}{l}\text { Groupware (e.g. Lotus Notes), Computer-aided } \\
\text { design (e.g. Auto CAD for product modeling and } \\
\text { Matrix for documentation system), Graphical } \\
\text { simulation tools, Geographic information sys- } \\
\text { tems (GIS); Enterprise Knowledge Portals... }\end{array}$ \\
\hline \multirow{2}{*}{ 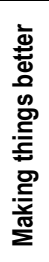 } & $\begin{array}{l}\text { IT } \\
\text { business process } \\
\text { support }\end{array}$ & Process managers & $\begin{array}{l}\text { Project and process } \\
\text { management across } \\
\text { demand / supply chain }\end{array}$ & $\begin{array}{l}\text { Enterprise resource planning systems (ERP) } \\
\text { (e.g. SAP, Navision...); Production, distribution, } \\
\text { inventory, and sales management systems; } \\
\text { Workflow automation systems... }\end{array}$ \\
\hline & $\begin{array}{l}\text { IT } \\
\text { operational } \\
\text { support }\end{array}$ & $\begin{array}{l}\text { Operational workers } \\
\text { and supervisors }\end{array}$ & $\begin{array}{l}\text { Transaction processing } \\
\text { Direct operations }\end{array}$ & $\begin{array}{l}\text { Payment systems; Order processing systems; } \\
\text { Policy management systems; Accounting, pay- } \\
\text { roll and personnel systems; Checking, credit } \\
\text { cards systems... }\end{array}$ \\
\hline
\end{tabular}

Figure 1: IT Practices support overview 


\section{Information Management Practices (IMP)}

"Information Management Practices (IMP) are capabilities of a company to manage information effectively over the life cycle of information use including sensing, collecting, organizing, processing, and maintaining information," (Marchand et al., 2001a). The theoretical basis of "IM School" lies in resource management. Specifically, Horton (1968) was concerned about treating information as any other organizational resource and that information has to be tracked and managed through its life-cycle. IM School failed to draw tight link between improved information resource management and better business performance. This was mainly due to the fact that with little authority (and necessary skills) "librarians" had little impact in the broader information management practices and people behaviors that shape how information is or should be used in the company to improve business performance.

If IT practices refer to the management of IT applications and infrastructure, IM practices focus on the company's capabilities to effectively manage the use of information over its life cycle in support of coordination and control, tactical problem solving and strategic decision making. If company's information management is not adequate, following flaws are commonly visible: failures to respond in a timely way; duplication of effort; failures to exploit information that is already available in company, information overload.

The research (Navigating Business Success) showed that executives have clear notion of good information management practices as being a cycle with five interrelated phases. Sensing is essential to high level of IMP maturity as companies must continuously identify events, trends and changes in business conditions and make sense out of them to collect appropriate information, develop new strategies, or make decisions. With the issue of relevancy of information it has straight influence on collection of relevant information where care has to be taken to avoid overor under-load of information. Only the right type and amount of information is acceptable to avoid over- or under-load, and knowledge residing in employees must be identified and made explicit; information behaviors and values need to be trained and rewarded as employees tend to perceive collecting of information they don't directly use as low priority part of the job. Organizing information depends firstly, on collecting phase, and secondly, on good IT support. In processing, analysis of data is a critical step, since decision makers transform data into information which, with meaning added, transforms into knowledge that is used by most of employees today to perform their everyday jobs. Processing is, besides sensing, one of the most critical aspects of information management, as at this point people evaluate the relevance and importance of information to their needs and, accordingly, determine whether information is to be maintained for the future use or discarded. Special attention has to be paid to hiring, ongoing training, evaluation and rewarding of employees to ensure that company has hired the right people to process information into knowledge. Maintaining involves reusing and refreshing existing information to avoid expensive and time-consuming double collection. Reusing is linked to values and behaviors of employees, as at times existing people might assume that old information is stale; they might not be aware that information exists; managers sometimes redefine decisions and encourage new data collections...

Interrelation of IMP capabilities and their connection to Information Maturity is presented in Figure2; it is necessary to point out that these relationships are in circular, not linear form and it is difficult to say where the life circle of information begins or ends. Holistic approach in their development is recommended, since sensing and processing are the most critical practices, yet on the other hand all others should not be left behind. 


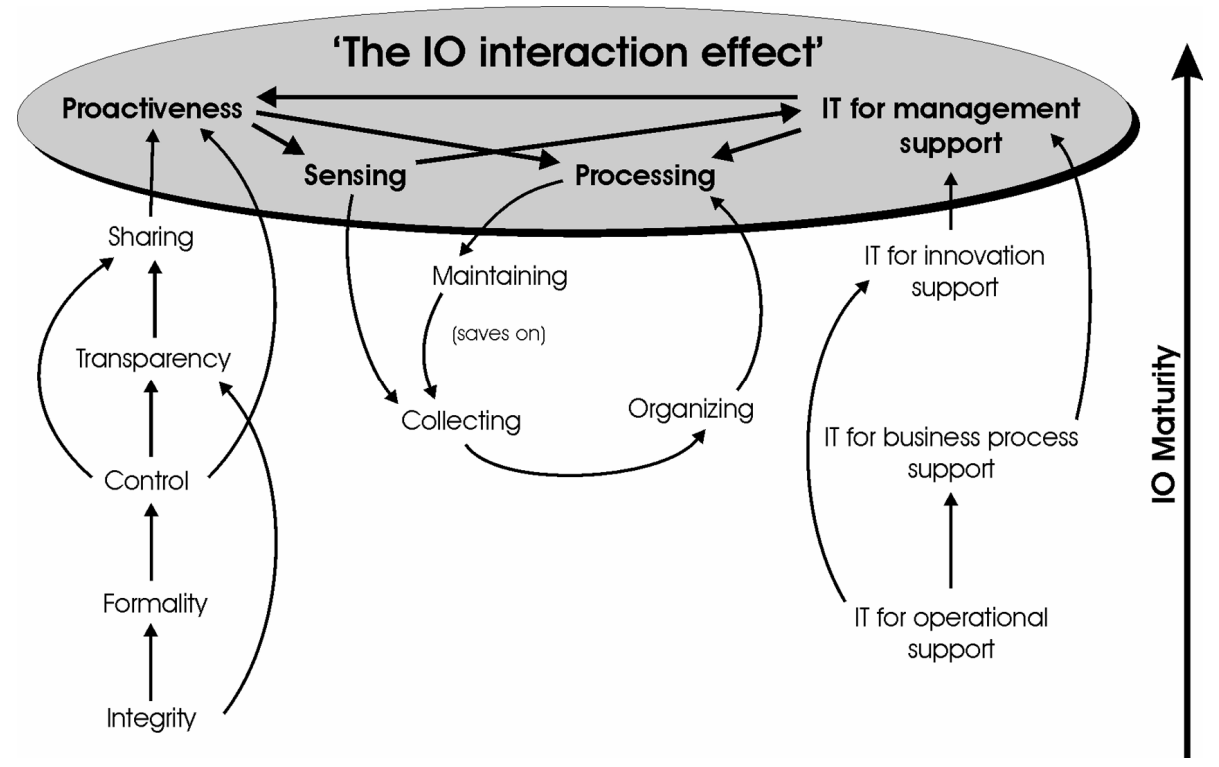

Figure 2: The IO maturity model: cross-capability linkages

\section{Information Behavior and Values (IBV)}

Unlike IT and IM School, there is no comprehensive theory on instilling effective information usage behaviors. Two views are known in the literature, the Human resources view and the Management control view, yet none of them addresses the relationship between the management of people and how people use information to achieve company's goals. IT and IM disciplines did not deal with improving the information usage behaviors and values of the employees due to the fact that they were "operational level support functions" and they had little influence on changing people's behaviors. Besides, influencing people requires very different skills and is much more difficult than dealing with new software.

It is ill-fated circum-stance for the IBV practices to be an informal and underdeveloped discipline, as companies involve relationships among people, and how they choose to contribute their knowledge to achieve company's or group purposes instead of or together with pursuing their own interests. A challenge for managers is to define a relevant context, or orientation, to channel human attention, information use, and human knowledge and learning into creative ideas and information of value to achieve business success.

In the mindset of senior executives, there are six IBV capabilities, which are closely related. Integrity acts as the basis for information use, setting appropriate boundaries for ethical information behavior, and influencing directly the formal use of information within a company which improves reliability and quality of information used. Improvements to formal information use will have a direct impact on the ability of a company to provide information control, which is the use of performance information among managers and employees at all levels of a company. As everyone knows how (and why) a company is doing, information about performance stimulates open discussion of problems and emergence of new ideas to improve performance at all organizational levels. Transparency is evident when members trust each other and talk freely about failures and mistakes. Sharing of sensitive and non-sensitive information is facilitated by transparency and control, as open discussion about known problems is treated as opportunity to learn, not opportunity to whitewash the managers and punish the employees. Proactiveness is the most wanted practice and executives see it as how well people in company think about using information to create or enhance products and services, and how promptly they respond to business changes they foresee. 


\section{Information Orientation}

The "Navigating Business Success" research explained CEOs' view of the business information system. Their expectations have been presented in the above three sections and they are also visible from the IO maturity model (Figure 2) which shows how each of the fifteen competencies (within the mentioned three information capabilities that managers associate with effective information use) influences each other. "Better" companies try to develop competencies in the shaded area of the picture s simultaneously and create powerful "spiral" effect, in which excellent IT capabilities influence good information behaviors and good information management. Good information management in turn influences better IT capabilities; good information behavior on the other hand improves information management.

Senior managers recognize that successful companies must be good at all three information capabilities to reap the substantial benefits from cross-capability interactions involving using information proactively, sensing and processing information appropriately, and deploying IT for management support. Good information usage behaviors and values drive better information definition and management; this improves the capability of a company to use IT to support decision making and problem solving, which in turn reinforces good information usage behaviors and values.

Thus, in contrast to 'traditional' views on information in a company, information use in companies on an aggregate level is people-centric. It is based on the decision-context and the tasks that people must execute to achieve organizational purposes.

It not only involves how people use IT and manage information to help improve decisions, but rather how they behave with information based on values associated with effective information use.

\section{Educational Issues}

\section{Framework of (Relevant) Educational Program}

The breakdown of 'information orientation', considered in previous section, leads to new aspects of how information, people and IT are leveraged to increase business performance. Deficiency in any of the three key information orientation capabilities: information technology practices (ITP), information management practices (IMP) and information behavior and values (IBV), will lead to inverted spiral effect and thus worse business performance.

Such aggregate view is senior managers' view on key information systems and business professionals. CIO in particular has to be a 'hybrid' business and information systems manager who can play a major role in strategy formulation for effective use of information technology, who does not neglect the human side of the information equation, and who does not forget that information has to be managed like any other resource, and thus puts the 'I' back in the 'IT'. Only than can a company start using information proactively, sensing and processing information appropriately, and deploying IT for management support. Such view has to be comprehended by every single employee as well, especially by knowledge workers.

In that, graduate and postgraduate programs that educate future business and businessinformation systems professionals obviously play a very important role. As known from the human-resource-management and organizational theories, the 'human' side of the organization, especially values, can take months and years to change. This is why it is so critical to have higher education institutions with proper and relevant curricula. It is often the case that higher education MScIS, Information Management and MBA study programs put forward topics that are 'native' to lecturers. Or, as IT and IM schools are well developed disciplines, it is quite simple to go 
astray and forget about the information behaviors and values, which in turn - as we have seen are essential part of mature information capabilities of organization. Thus it is of vital importance to deliver such curricula which include topics that cover each of the three information capabilities. It is obvious that old IT (or in a little better case, IT/IM) programs do not sustain sufficient degree of relevancy to the needs of present-day business community. The skills expected from every business-information professional have changed and if not already, many universities will be forced to revise or even rebuild their curricula from scratch. In practice, a successful CIO is far from being merely 'a technological geek'. According to a research (Earl, 2000), the most important qualities of knowledge workers, especially CIO, are: a shared vision of changed business and ability to work closely with peers and superiors; both a willingness to pay attention to day-to-day IT performance and excellent understanding of business process; and finally, ability to consult and lead a company when going through significant changes encompassing technological and human side of the change that lead to desired behaviors and values of all employees. Below a few guidelines are set to help check and rebuild the curricula.

Regarding the content of the study program, a framework of topics in education of future business-information systems professionals, known as "the Amsterdam model", is presented in Figure 3 (Maes, 2003). It was developed by and it is being used by successful Information Management postgraduate and research program at University of Amsterdam ("Executive Masters in $I M$ ") and it states that a full comprehension of information management entails that it has to be studied interdependently at the strategic, (infra)structural and operational level as well as that IM relates the (external and internal) information and communication processes and their supporting technology to general business aspects (Maes, 1999, 2003, 2004; Wisse, 2002).

Authors of the framework believe that tradition-

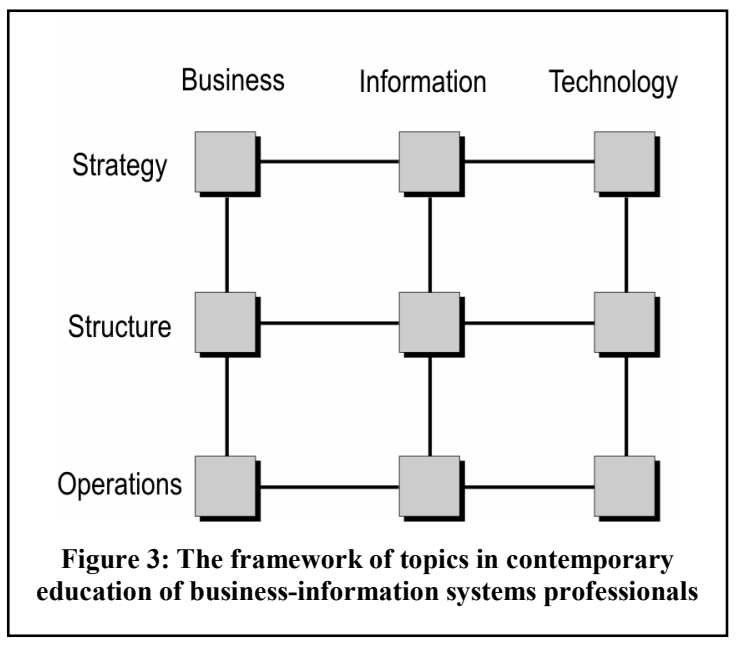
ally, research in information management has paid (and is still paying) a lot of attention to information technology as such and to the direct business-information technology link, for instance in terms of strategic alignment (as it was, in example, influentially proposed in 1992 by Henderson \& Venkatraman, or in 1997 advocated and used to design an educational model with by Burn \& Ma). Recent experience, however, indicates that these approaches miss two crucial linking pins for information technology to add value to business and for business to exploit the dematerialization of economic activity: 1) 'information and communication' as intermediary, mediating concepts bridging business and information technology, and 2) 'architecture and infrastructure' as similar concepts bridging the strategic and operational levels of organizational attention (Maes, 2003, p. 254).

As to 'information and communication', it is noticed that its importance has recently been augmented by information technology being put at a certain distance of the business (e.g. by outsourcing), as a result of what the organization of the information 'demand side' has become paramount. A further consequence of the growing attention for information and communication is that new, immaterial concepts such as emotion, learning, sense making, knowledge, experience, identification, and trust are gaining importance in information management as they do in economic activities in general (Choo, 1998; Huizing \& Bouman, 2002; Pine \& Gilmore, 1999 as cited by Maes, 2003, p. 254). Following that, information management and information behavior and values should be very important (if not the most important) part of education in the area. 
With regard to 'architecture and infrastructure', it can be said that companies are increasingly discovering that information management is not exclusively aimed at the support of business strategy, yet at least as much at that of business operations. The volatility of present-day strategy and the observation that strategy is only indirectly influencing operations further add to the importance of 'infrastructure and architecture' as linking pins, both in a theoretical and a practical sense.

The model presented enables a clear positioning of the actual problem (and research) area, or better said, topic, in the framework of educational program. Also, it can be used to explain (see Figure 4) five global roles of the CIO (as set by Maes 2004, p.12): 1) information strategist, 2) co-creator of business strategy, 3) IT portfolio manager, 4) organization architect, 5) business advisor and 6) trend watcher.

According to Bruce (1999), the teaching/learning model, firstly, should be theory-based as 'innovative variations' have to be based on firm anchors. Also, doing theoretical research for assignments improves students' abilities like collecting and organizing the information, making sense of information, deciding which information is important and which not, etc. Secondly, it should be action-oriented: if possible, real-life projects from business world should be under-taken, as "care for companies should be integral part of any managerial learning process, just as patient care is part of any medical training program," (Maes, 2003). Also, there should be a final-year-module(s) or project(s) that deal with implementation or/and change issues, encompassing all of the aspects as a whole. Important behavior skills and values can be improved by that, such as functioning as a part of a team, trust-building, communication about mistakes, taking responsibility for them and dealing with them, sharing of information (instead of hoarding), etc. Both mentioned ideas, the theory-based and action-oriented education, emphasize conceptual skills and intellectual agility. Third, the faculty of the education institution should be complemented with external practitioners to ensure that practical relevance of the program exists.

The most important thing for educators and policy makers to constantly keep in mind is that the observable learning outcomes in real-life are not written assignments nor grades or course credits earned: they are demonstrations of 1) what the student knows, 2) what the student can actually do with what s/he knows, and 3) the student's confidence and motivation in demonstrating what s/he knows (Bouslama, Lansari, Al-Rawi \& Abonamah, 2003). These outcomes are immediately put up against senior managers' expectations when our graduate hits the 'real life' and therewith our education program can be evaluated.

\section{Analysis of Curriculum: Case Study of Information Systems Management Program at Faculty of Economics, Ljubljana, Slovenia}

Faculty of Economics, University of Ljubljana, has been one of the first Slovenian higher education institutions to accept and start implementing the Bologna Declaration. In the process all of the study programs at the Faculty have recently been re-set up from the scratch, and so was also the Information Management graduate and postgraduate program.

In this section, the newly developed program is revised and verified whether it sustains sufficient degree of relevancy to the needs of present-day business community. This analysis in final sec- 
tion, together with this section's recommendations in content/delivery areas, can serve as a guideline when building, revising and endorsing contemporary and relevant curricula for similar educational programs.

\section{On Bologna Declaration}

In June 1999 education ministers from around 30 of European countries had met in Bologna and undertaken in a joint declaration (the Bologna Declaration) to establish a European area of higher education by 2010. "In particular, the Declaration wants to increase the international competitiveness of the European system of higher education," (The Bologna Declaration, 2000; The Bologna Process, 2004).

The action program set out in the Declaration is based on a clearly defined common goal, a deadline and a set of specified objectives:

- a clearly defined common goal: to create a European space for higher education in order to enhance the employability and mobility of citizens and to increase the international competitiveness of European higher education;

- a deadline: the European space for higher education should be completed in 2010;

- a set of specified objectives:

- the adoption of a common framework of readable and comparable degrees, "also through the implementation of the Diploma Supplement";

- the introduction of undergraduate and postgraduate levels in all countries, with first degrees no shorter than 3 years and relevant to the labor market;

- ECTS-compatible credit systems also covering lifelong learning activities;

- a European dimension in quality assurance, with comparable criteria and methods;

- the elimination of remaining obstacles to the free mobility of students (as well as trainees and graduates) and teachers (as well as researchers and higher education administrators).

In this move towards shorter studies, 2-tier degree structures, credit systems, external evaluation, and more autonomy coupled with more accountability, the Faculty of Economics, Ljubljana, had to create a new set of under and post-graduate study programs. This significant task has been treated as a challenge and a perfect opportunity to ventilate and recast content of existing courses, including the program of Information Management.

\section{Analysis of the curriculum}

According to Bologna Declaration, a two-tier degree program of Information Management has been set up. Full program curriculum is exposed in Table 1 and analyzed with help of Figure 5, which introduces a list of all subjects into the "Amsterdam" framework of topics in contemporary education of future business-information systems professionals.

Brief analysis gives impression that each of the nodes in the enneahedron is covered. Yet, an indepth analysis shows that on the downside, the program is still paying a lot of attention to information technology as such and to the direct business-information technology link, for instance in terms of strategic alignment. However 'linking pins' for information technology to add value to business and for business to exploit the dematerialization of economic activity ('information and communication' as bridge between business and IT, and 'architecture and infrastructure, bridging strategic and operational levels of organizational attention (Maes, 2003, p. 254)) should be covered better. 
Evidence gathered from successful study programs shows that the organization of the information "demand side" (the middle column) has become paramount, as IT is only indirectly influencing the business (viz. by the information generated, the communication supported etc.), and as the quality of information use is seriously filtering the impact of IT (Maes, 2004). The most important observation regarding this is that "our" Information and communication (middle) column is underdeveloped at this time. Curriculum should pay more attention to middle column some of the topics in the field of support of information management strategy and in the field of support of IM operations (like enterprise content management, information policies, information audit, knowledge management on strategic level, KM from infrastructural view, IT support for $\mathrm{KM}, .$. ) are missing completely, and some are covered only superficially, i.e. as a small share in one of the other (IT or business) subjects.

Regarding the teaching/learning model, we find through detailed analysis of each of the subjects that the program is set up accordingly to guidelines written in previous section. It is both theory based and action oriented. Theoretical research leads to well-read students and improves information management skills; on the other hand undertaking real-life projects from business world improves understanding of the area and creates a wide set of practical experience, i.e. in team work, trust-building, communication about mistakes, taking responsibility for them and dealing with them, sharing of information (instead of hoarding), etc. Finally, the faculty is complemented with external practitioners to ensure that practical relevance of the program exists.

Table 1: CURRICULUM: INFORMATION SYSTEMS MANAGEMENT Undergraduate level

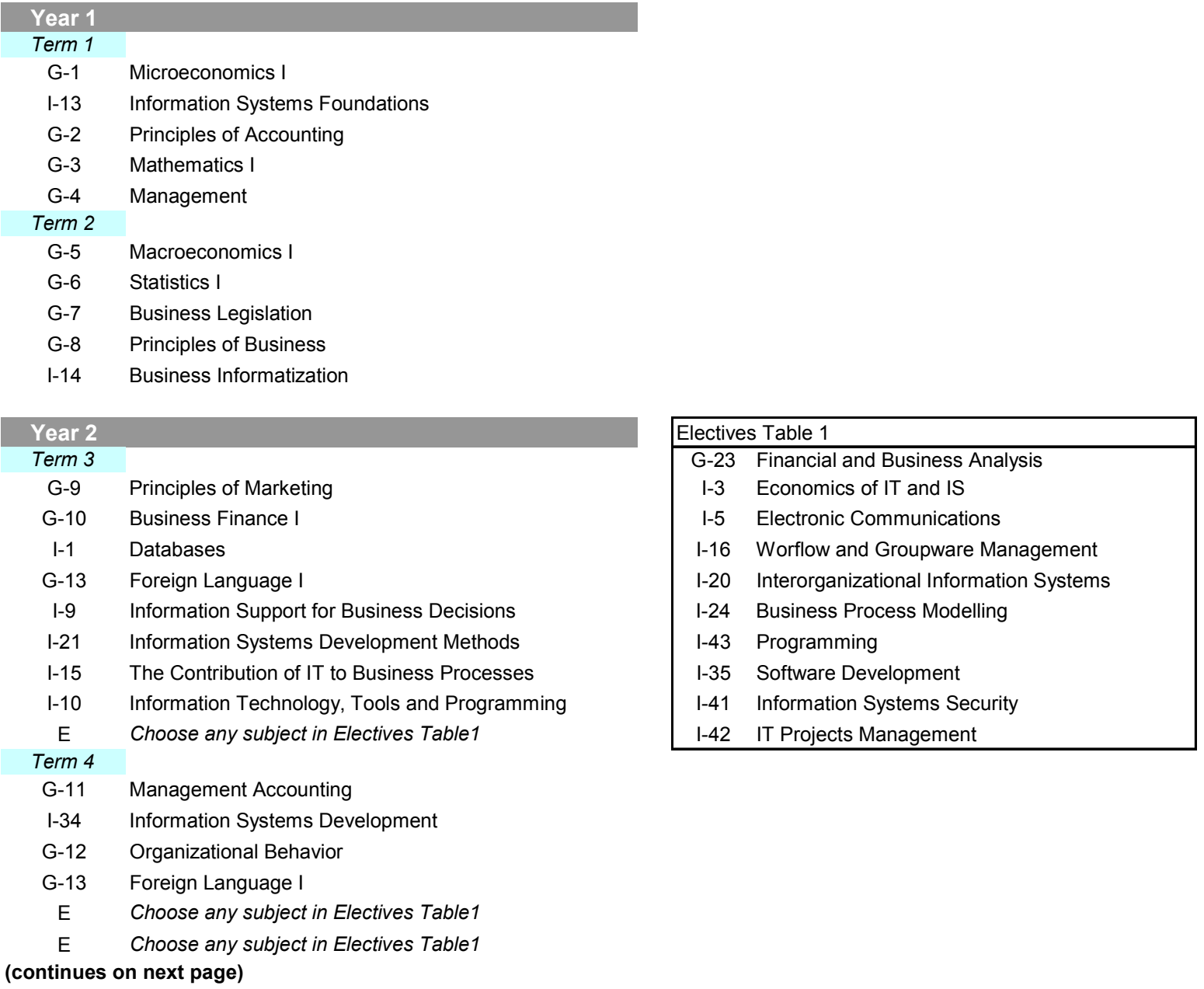




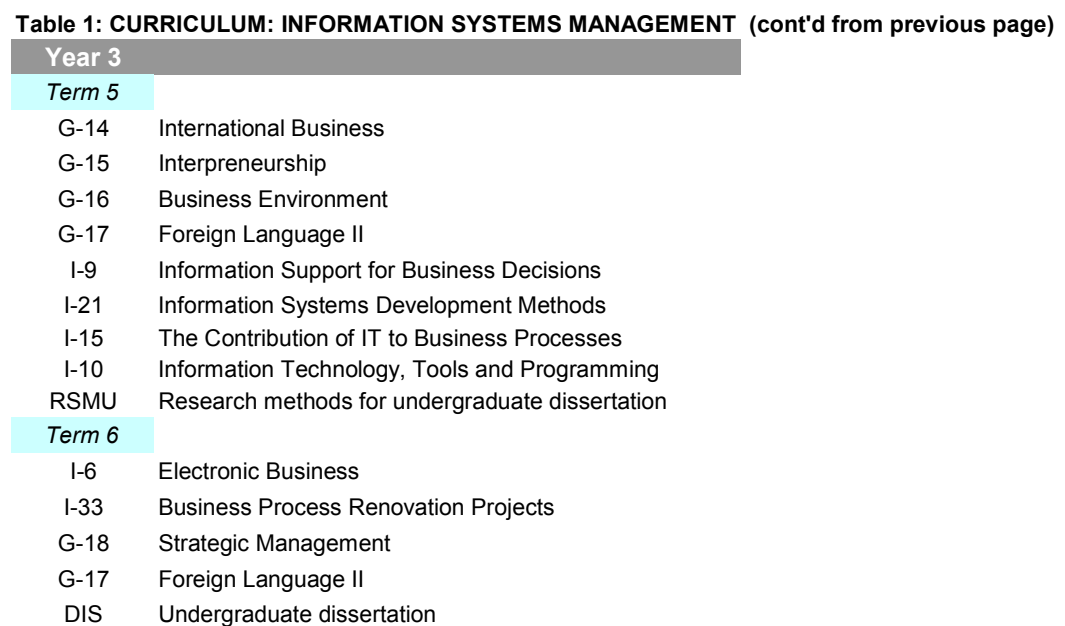

CURRICULUM: INFORMATION SYSTEMS MANAGEMENT

\section{Postgraduate level}

\begin{tabular}{|c|c|}
\hline \multicolumn{2}{|c|}{ Year 1} \\
\hline \multicolumn{2}{|l|}{ Term 1} \\
\hline G-19 & Microeconomics II \\
\hline G-20 & Research Methods \\
\hline G-21 & Theory of Organization \\
\hline $\mathrm{I}-21$ & Information Systems Development Methods \\
\hline \multicolumn{2}{|l|}{ Term 2} \\
\hline G-22 & Statistics II \\
\hline G-23 & Strategic Management II \\
\hline $1-32$ & Business Renovation \\
\hline $1-22$ & IT Projects Management Methods \\
\hline $1-39$ & Data and Process Management \\
\hline $1-25$ & Advanced IS Modelling \\
\hline$E$ & Choose any subject in Electives Table2 \\
\hline$E$ & Choose any subject in Electives Table2 \\
\hline \multicolumn{2}{|l|}{ Year 2} \\
\hline \multicolumn{2}{|l|}{ Term 3} \\
\hline $1-32$ & Business Renovation \\
\hline $1-22$ & IT Projects Management Methods \\
\hline I-39 & Data and Process Management \\
\hline $\mid-25$ & Advanced IS Modelling \\
\hline $\mathrm{I}-17$ & Information Systems Auditing and Quality Assurance \\
\hline I-36 & Decision Support Systems \\
\hline $1-40$ & Knowledge Management \\
\hline I-18 & Information Systems Management \\
\hline E & Choose any 1 in Electives (Table2) \\
\hline$E$ & Choose any 1 in Electives (Table2) \\
\hline$E$ & Choose any 1 in Electives (Table2) \\
\hline \multicolumn{2}{|l|}{ Term 4} \\
\hline DIS & Postgraduate dissertation - Masters Thesis \\
\hline
\end{tabular}

\begin{tabular}{|cl|}
\hline Electives Table 2 \\
\hline I-4 & Economics of Telecommunications \\
I-45 & Expert Systems \\
I-7 & E-marketing \\
I-8 & Information Society \\
I-19 & Customer Relationships Management \\
G-24 & Supply Chain Management \\
I-44 & Advanced Programming \\
G-25 & Managing Costs \\
I-27 & Data Mining \\
I-29 & Business Modelling and Change Management \\
I-30 & Legal Aspects and Standardization in IS \\
I-46 & Production Information Systems \\
I-37 & Telecommunication Services and Technologies \\
I-38 & Strategic IS Planning \\
\hline
\end{tabular}




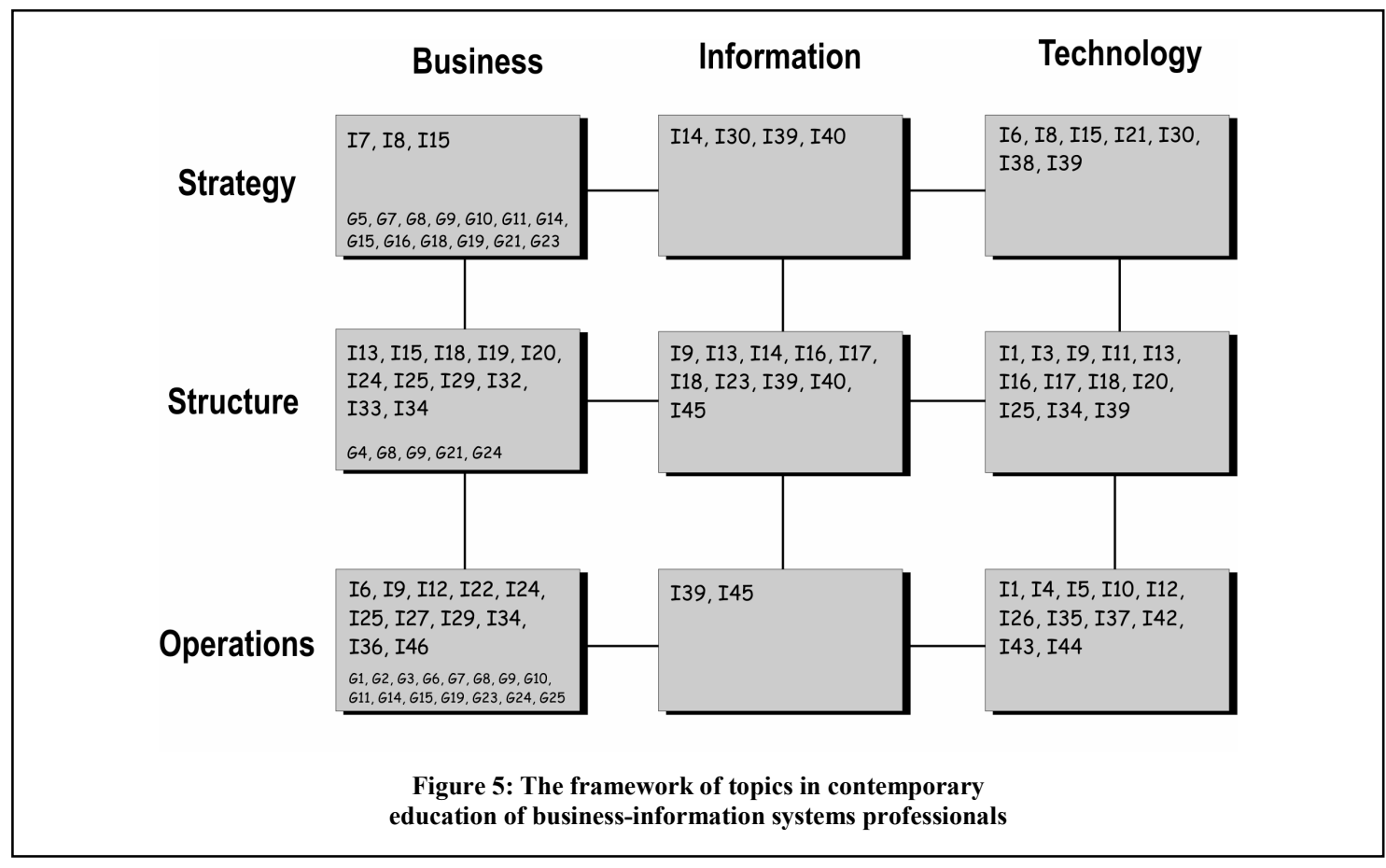

\section{Conclusion}

It used to be believed that a) only technology or b) only information management can improve business performance and a) IT or b) information is the most important currency in building and maintaining a competitive edge. Yet, a research (Marchand et al., 2001b) in the field of effective information use proved that using information is too important to be left solely to IT and/or information specialists. Information is only as effective as the weakest link - with the best technology yet without managers and business people with appropriate skills and experience to use it, one is limited by organizational competence. If the company has strategic vision and strong products in the marketplace, but it doesn't have the IT to support them, then one is constrained by technology.

Following that, CIO of the new age has to be a 'hybrid' business and information systems manager who can play a major role in strategy formulation for effective use of information technology, who does not neglect the human side of the information equation, and who does not forget that information has to be managed like any other resource and thus puts the 'I' back in the 'IT'. Only a strong interaction of people, information and technology can improve business performance.

As companies have to be equally good at using information proactively, sensing and processing information appropriately, and deploying IT for management support, and as information orientation has to be people-centric by default, proper curricula is expected from higher education institutions. The expectations of the business community were firstly presented in the paper; both descriptions of information capabilities combined and ideas, developed in the last section can serve as a guideline when building, revising and endorsing curricula.

A graduate and postgraduate program that has recently been developed at the Faculty of Economics, University of Ljubljana, has been reviewed whether it sustains sufficient degree of relevancy to the needs of present-day business community. It was verified whether it offers a complete and relevant set of topics. A "blind spot" in the educational program has been located as analysis showed that curriculum is still paying a lot of attention to information technology as such and to 
the direct business-information technology link, for instance in terms of strategic alignment. Information and communication (middle) column is seriously underdeveloped in our program at this time.

In order to "create" successful future CIOs, who could act as information strategist, co-creator of business strategy, IT portfolio manager, organization architect, business advisor and trend watcher, curriculum should be revised and improved in the area of middle column.

\section{References}

Abcouwer A.W. (2004). Who is managing the information? About the work of the information manager and his CIO. PrimaVera, working paper 2004-14. PrimaVera Working Papers Series. Amsterdam: Universiteit van Amsterdam.

Anthony, R.N. (1965). Planning and control systems: A framework for analysis. Boston: Harvard Business School Division of Research Press.

Baloh, P. (2004). Returning the 'I' in the 'IT' education of MScIS/MBA professionals. Journal of Issues in Informing Science and Information Technology, 1, 915-929.

Barua, A., Kriebel, C., \& Mukhopadhyay, T. (1995). Information technology and business value: An analytic and empirical investigation. Information Systems Research, 6 (1), 3-23.

Bharadwaj, A. (2000). A resource-based perspective on information technology capability and firm performance: An empirical investigation. MIS Quarterly, 24 (1), 169-196.

Bouslama, F., Lansari, A., Al-Rawi, A., \& Abonamah, A. A. (2003). A novel outcome-based educational model and its effect on student learning, curriculum development, and assessment. Journal of Information Technology Education, 2, 203-214.

Bruce, C.S. (1999). Workplace experiences of information literacy. International Journal of Information Management, 19 (1999), 33-47.

Burn, J.M., \& Ma, L.C.K. (1997). Innovation in IT education - practicing what we preach. Information Resources Management Journal, 4 (10), 16-25.

Cash, J., \& Konsynski, B. (1985). IS redraws competitive boundaries. Harvard Business Review, 63 (2), 134-142.

Choo, C. W. (1998). The knowing organization. New York: Oxford University Press.

Davenport, T. H. (2000). Putting the I in IT. In D. A. Marchand, T. H. Davenport, \& T. Dickson (Eds.), Mastering Information Management. Financial Times Series, Prentice Hall.

Davis, B., \& Riggs, B. (1999). What's the investment worth? InformationWeek.com. Retrieved August 26, 2003 from http://www.informationweek.com/728/k2.htm (Last accessed December 1, 2003.)

Dos Santos, B.L., Peffers, K.G., \& Mauer, D.C. (1993). The impact of information technology investment announcements on the market value of the firm. Information Systems Research, 4 (1), 1-23.

Drucker, P. (1993). Professionals productivity. Across the Board, 9 (30), 50-51.

Earl, M. J., \& Scott, I. A. (1999). Opinion: What is a chief knowledge officer? MIT Sloan Management Review, 2 (40), 29-38.

Earl, M. J., \& Scott, I. A. (2000). The role of a chief knowledge officer. In D. A. Marchand, T. H. Davenport, \& T. Dickson (Eds.), Mastering Information Management. Financial Times Series, Prentice Hall.

Gorry, G. A., \& Scott Morton, M. (1989). A framework for management information systems. Sloan Management Review, Spring, 49-61.

Greco, J. (1999). What is a CKO-and should you have one? The Journal of Business Strategy, 2 (20). 
Henderson, J. C., \& Venkatraman, N. (1992). Strategic alignment: A model for organizational transformation through information technology. In A. Kochan, \& M. Useem (Eds.), Transforming organizations. Oxford and New York: Oxford University Press.

Hitt, L., \& Brynjolfsson, E. (1996). Productivity, profit and consumer welfare: Three different measures of information technology. MIS Quarterly, 2 (20), 121-142.

Huizing, A., \& Bouman, W. (2002). Knowledge and learning, markets and organizations: Managing the information transaction space. In C. W. Choo, \& N. Bontis (Eds.), The strategic management of intellectual capital and organizational knowledge (Chapter 11). New York: Oxford University Press.

Maes, R. (1999). Reconsidering information management through a generic framework. PrimaVera, working paper 1999-15. PrimaVera Working Papers Series. Amsterdam: Universiteit van Amsterdam.

Maes, R. (2003). On the alliance of executive education and research in information management at the University of Amsterdam. International Journal of Information Management, 23, 249-257.

Maes, R. (2004). Information management: A roadmap. PrimaVera, working paper 2004-13. PrimaVera Working Papers Series. Amsterdam: Universiteit van Amsterdam.

Marchand, D.A., (Ed.) (2000). Competing with information - A manager's guide to creating business value with information content. Executive development from IMD series. Chicester, England: John Wiley and Sons.

Marchand, D.A., Kettinger, \& W.J., Rollins, J.D. (2000). Information orientation: People, technology and the bottom line. MIT Sloan Management Review, 4 (41), 69-80.

Marchand, D.A., Kettinger, \& W.J., Rollins, J.D. (2001a). Information orientation: The new business performance metric. Oxford University Press, Great Britain.

Marchand, D.A., Kettinger, \& W.J., Rollins, J.D. (2001b). Making the invisible visible: How companies win with the right information, people and IT. Chicester, England: John Wiley and Sons.

McFarlan, F.W. (1984). Information technology changes the way you compete. Harvard Business Review, $62(3), 1984,98-103$.

McNurlin, B. (Ed.) (1991).Trends in information technology. Chicago, IL: Andersen Consulting.

Mintzberg, H., Ahlstrand, B., \& Lampel, J. (1998). Strategy safari: A guided tour through the wilds of strategic management. London: Prentice Hall Europe.

Orna, E. (1999). Practical information policies (2nd ed.).Gower, Great Britain: Aldershot.

Porter, M. E., \& Millar, V. E. (1985). How information gives you competitive advantage. Harvard Business Review, 63 (4), 149-160.

Pine, J. B., \& Gilmore, J. H. (1999). The experience economy. Boston: Harvard Business School Press.

Rogers, E., \& Agarwala-Rogers, R. (1976). Communication in organizations. New York: The Free Press.

Simon, H. A. (1946). Administrative behavior: A study of decision-making processes in administrative organization. New York: The Free Press.

Simon, H. A. (1960). The new science of management decision. New York: Harper \& Row.

Simons, R. (1995). Levers of control: How managers use innovative control systems to drive strategic renewal. Boston: Harvard Business School Press.

Strassmann, P.A. (1990). The business value of computers: An executive's guide. New Canaan, Connecticut: The Information Economic Press.

Strassmann, P. A. (1997, Februray). Will big spending on computers guarantee profitability? Datamation.

Stratopoulos, T., \& Dehning, B. (2000). Does successful investment in information technology solve the productivity paradox? Information \& Management, 38 (2000), 103-117.

Streatfield, D., \& Wilson, T., (1999). Deconstructing Knowledge Management. Aslib Proceedings, 3 (51). 
Swash, G. D. (1997). The information audit. Journal of Managerial Psychology, 12 (5), 312-318.

Tam, K. Y. (1998). The impact of information technology investments on firm performance and evaluation: evidence from newly industrialized economies. Information Systems Research, 9 (1), 85-98.

The Bologna Declaration (2000). On the European space for higher education: An explanation. Retrieved from http://europa.eu.int/comm/education/policies/educ/bologna/bologna.pdf (Last accessed December 09, 2004.)

The Bologna Process (2004). Last accessed December 09, 2004 at http://europa.eu.int/comm/education/policies/educ/bologna/bologna_en.html

Wisse P. (2002). Multiple axiomization in information management. PrimarVerma Working Paper 200206. PrimaVera Working Papers Series. Amsterdam: Universiteit van Amsterdam.

\section{Biography}

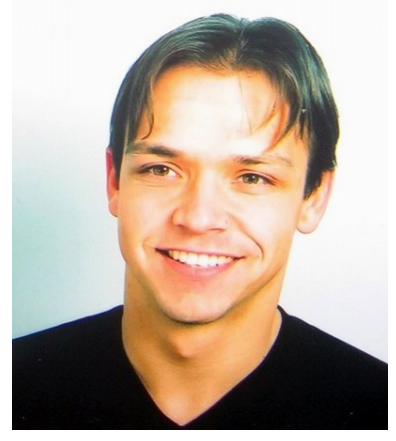

Peter Baloh, MSc., is an assistant lecturer for Information Management at Faculty of Economics, University of Ljubljana, Slovenia. His main research interest is concentrated around the question of influence of contemporary Information Technologies and Information Management as a whole on business performance. Topics of interest in view of that include business informatization, knowledge management, project management and IT support, information system audits, business process modeling, stochastic financial modeling, and education in the field. 